\title{
PERCEPTION OF INTERDIALECTAL ACCOMMODATION BY SELLERS AND BUYERS IN SASAK: A SOCIOLINGUISTIC PERSPECTIVE
}

Persepsi Akomodasi antardialek oleh Penjual dan Pembeli dalam Bahasa Sasak: Perspektif Sosiolinguistik

\author{
Abdul Muhid ${ }^{a}$ dan Sri Ningsih ${ }^{b}$ \\ ${ }^{a}$ Universitas Bumigora \\ Jalan Ismail Marzuki No.22, Cilinaya, Kota Mataram, Nusa Tenggara Barat, Indonesia \\ ${ }^{b}$ Akademi Kebidanan Tahirah Al Baeti \\ Jalan Abdul Azis No.70B, Tanah Kongkong, Kabupaten Bulukumba, Sulawesi Selatan, Indonesia \\ abdulmuhid@universitasbumigora.ac.id,inci_jica@yahoo.co.id
}

Naskah Diterima Tanggal 12 Desember 2020-Direvisi Akhir Tanggal 7 Oktober 2021—Disetujui Tanggal 1 Desember 2021 doi: https://doi.org/10.26499/rnh.v10i2.4039

\begin{abstract}
Abstrak
Penelitian ini berfokus pada strategi komunikasi yang digunakan oleh penutur dua dialek yang berbeda antara meriaq-meriku vs meno-mene dalam bahasa Sasak, khususnya antara penjual-pembeli di ranah pasar di Lombok Tengah Nusa Tenggara Barat. Data tersebut direkam di empat pasar tempat bertemunya penutur dari dua dialek yang berbeda. Hasil saat ini mengungkapkan strategi yang efektif dalam komunikasi dengan saling mengakomodasi (penjual-pembeli). Selanjutnya diuraikan strategi pola akomodasi dalam dua dialek yang berbeda yang biasa digunakan oleh penjual-pembeli dalam melakukan transaksi. Peneliti saat ini menyusun data melalui wawancara, observasi langsung, dan pencatatan atau pencatatan. Metode yang digunakan untuk mengungkap fenomena tersebut adalah metode kualitatif dan menginterpretasikan data untuk memenuhi hasil penelitian yang memenuhi syarat. Oleh karena itu, hasil penelitian menunjukkan bahwa penerapan akomodasi antar dialek efektif.
\end{abstract} Kata-kata kunci: persepsi, akomodasi, penjual-pembeli, sosiolinguistik, antar dialek.

\begin{abstract}
This research focuses on the strategy of communication which was used by the speakers of two different dialects between meriaq-meriku vs meno-mene in Sasak language, especially amongst sellers-buyers in markets domain in central Lombok West Nusa Tenggara. The data were recorded at four markets where the speakers of two different dialects meet. This current result reveals the effective strategy in communication by accommodating each other (sellers-buyers). Further, it elucidates the accommodation pattern strategy in two different dialects which are commonly used by the sellersbuyers in doing transactions. The current researchers composed the data through the interview, direct observation, and recording or note-taking. The method used to reveal the phenomenon is a qualitative method and interpreted the data to meet the qualified result of research. Therefore, the result shows that applying inter-dialectal accommodation is effective.
\end{abstract}

Keywords: perception, accommodation, sellers-buyers, sociolinguistics, inter-dialectal.

How to Cite: Muhid, Abdul dan Sri Ningsih. (2021). Perception of Interdialectal Accommodation by Sellers and Buyers in Sasak: A Sociolinguistic Perspective. Ranah: Jurnal Kajian Bahasa. 10(2). 283-292. doi: https://doi.org/10.26499/rnh.v10i2.4039 


\section{INTRODUCTION}

A language and social interaction in the group of people are continuum which is un-separable one to another. Language as an identity is firmly attached to the speaker of that language, even with a dialect merely. With dialect people can show their character to other people. Many of the group members maintain their language or dialect while in contact with others or may converge the dialect among the interactants. In fact, societies use language to communicate among interactants, for instance, in daily communication, at the office, at the airport, at the market, and in many other situations. However, the societies are prone to find the best communication strategy to transmit the idea while they are interaction. Since, the communicators come from different background, in terms of dialect, style of communication, gesture and even behavior. Hence, societies must do accommodation, particularly in the notion of convergence. It is caused by some factors, such as the political issue, economic issue, cultural issue, and the like. Therefore, strategy of communication is required to make conversation runs well. Thus, this strategy of communication is supposed to be such an effective way to succeed in the negotiation Giles et al. (2010).

A similar activity of the speakers adjustments have also been studied and given different term or name like coordination Brennan \& Clark (1996) and Clark (1996). Those different terms are actually shown similar meaning. In the current research, the researchers reveal some patterns of accommodation or convergence used among interactants (sellersbuyers) in Sasak community. An inter-dialectical accommodation is a dialect that goes beyond its territory whereby the community of its dialect switches to another dialect when they interact. Usually, they do this for a certain reason, for instance, they negotiate something with other people of different dialects. As a result, they meet the same perception toward the goal of the discussion. The societies posit that doing convergence is positively received but not always be so.

However, the current research mainly focuses on the patterns of inter-dialectical Accommodation or convergence between two dialects; meriak-meriku and meno-mene which are used by sellers and buyers in central Lombok. In the current research, the researchers directly participate in the field of research to assure the validity of data required, Clark (1996) and Labov (2010). Therefore, he maximally exists at the location where the social interaction existed. Another word, the convergence as a strategy of communication is to simplify the different and accentuate the similarities among the interactants. Essentially, most people consider that doing convergence in the communication will assist them to minimize the difference among them Andre (2016). Hence, in the current research, we are prone to emphasize the discussion on the patterns of inter-dialectical accommodation among the speakers of different dialect.

Many of the former studies on sociolinguistic found that language attitudes were the foremost factor that causes people to shift from one language to another language, especially dialect. As had been researched by Robert (1999) about the language shift and maintenance in three communities; Samoan, Dutch, and Gujarati. According to Shameem (1995) in his book entitled bilingualism, he stated the reason for people in maintaining the language was to maintain their ethnic language attitudes. In line with Hofstede $(1989,2011)$ in his articles, he defines culture as the "collective programming of the mind, which distinguishes the members of one group from another". Further, he noted that the "values, beliefs, assumptions, expectations, attitudes and behaviors" of individuals are part of a collective national character resulting from cultural mental programming. The purpose of sociolinguists doing research were to reveal the nature of phenomenon deals with language use in the societies. Hundreds of documentations as proof of language variation that have been done by researchers. Hence, 
the current research also tries to reveal how the phenomenon of interdialectal accommodation meet the point of talks event they use different dialect.

This current analysis reports the sociolinguistics phenomenon over the communication accommodation among members of speakers of a different dialect. Due to the general claim that language bridges a social life amid society, it takes a crucial role. Without it, it will impede social activity. Hence, this investigation is done to see the effectiveness of interdialectal accommodation among sellers and buyers in some markets in central Lombok, and how the speakers perceive it.

Generally, when the interactants are conversing some ideas with people of different dialect, they would find difficulties to understand each other. However, in the current research also reveal how both parties speak reciprocal dialect in communicating their ideas. It seems that the phenomenon is quiet dramatic alteration among the speakers. Normally, the talkers use their own language or dialect to extend their ideas but not always be so, and it will become the uniqueness of its investigation.

The data collection used by the researchers to gain the data for the current research was done in several ways, such as: recording, note taking, and interview. However, the peculiar method was also involved in this research, namely, capability adjustment, it reveals the ability of the speakers to adjust the dialect while doing conversation. For example, the interactants (speakers) could spontaneously alter the dialect to the interlocutors. Such as imitating some dictions, phare, sentence including the way they pronounce them. Attitude judgement, the ability of the interactants to create situation of intelligible and pleasant to the interlocutors. According to Preston (1989) in his prior research was also applied the similar technique to the research participants.

Another technique used to gain the data for this research was private technique. Here, the researchers should ask the speakers at the end of the record where the speakers from, the researchers recorded the voice of the speakers without recognized by the interactants. This result, give more validity and more confidence to the researchers to reveal their research results. Another expert technique Lambert et al. (1960) used different terms for their research, they named it matched-guise Technique. However, these techniques are done based on the solidarity. Hence the researchers propose the research question; How are sellers-buyers in Sasak, particularly the dialect of Meriak-Meriku vs Meno-Mene perceive the inter-dialectal accommodation?

\section{THEORETICAL BASIS}

This section provides some theories that covered to the research including some formers researches.

\section{Giles' Communication Accommodation Theory}

The theory of accommodation is developed from Speech Accommodation Theory (SAT) as has been proposed by Giles \& Smith (1979) and later it develops to Communication Accommodation Theory Giles et al. (1991). This theory formulates how to harmonize the communication among the interactants in order the communication meets a good end. Trudgill Trudgill (2003) simplifies the explanation that accommodation associates to convergence solely Hence, in this theory shows us how to accommodate our language and speech behavior. The basic concepts of the theory are; 1) speech behaviors in which people posit that human being has his/her own similarities and the differences, 2) the inner concept which is owned by every speaker to perceive the interlocutor's talk lead the speaker how to respond the interlocutor, and 3) language and behavior of the interactants bring several crucial information for the interlocutor, is that through the language he speaks and behavior he performs enable the brain of the interlocutor to determine the origin of the speaker. For 
instance, whilst Philippines' people talk with their particular accent the interlocutor can easily judge that the accent belongs to Philippines.

This theory mainly explains how people adjust their interpersonal while they are at communication interaction with other people. This idea is based on the behavior of people in society. They prone to adjust or adapt the similarity among interactants in the conversation. As mentioned above that this theory is developed by Giles while he introduces "Mobility of Accent" based on the accent used while doing an interview. In this situation the interviewee accommodates himself by adjusting his accent to the interviewer. Since the interviewer is in high position, while the interviewee is not. Thus, he is respect to the interviewer where he does interviews. This theory closely relates to social-psychology, in which it deals with cause and effect of one's behavior particularly in term of identity. Further, according to Giles and his colleagues explained the identity has a close relationship to the accommodation theory. On the other hand, the opinion of social identity theory also contributes a lot to the development of Giles' theory. For instance, while two people of different background meet together, they trend to compare each other. In short, while they have positive comparison, it bears a positive social identity.

As seen in the daily communication especially in social interaction, often people of different dialect change their dialect for a particular reason. It encompasses economy issue while trading or can be a political issue.

\section{Co-Cultural Theory}

This theory was proposed by Orbe (2017), it begins with an assumption in society that favors a group. In the sense that in social life there are dominant and non-dominant groups. So that in the life of social interaction, it will have an impact on communication which tends to be controlled by the dominant group, in other terms by Giles mentions the term divergence, which is an effort to maintain the identity of speakers by letting other people stay on the line of culture or language they use. Meanwhile, we as social beings will always live side by side with other cultures. This certainly has an impact on community members who live side by side with different cultures. So that this co-cultural theory emerged as an effort to find the right strategy to eliminate stereotypes in society. Because actually in social life there is no group that has a higher position compared to other communities proposed by Orbe (2017) as cited in Nurwahid (2020).

In Orbe's theory he proposed similar concept of communication as proposed by Giles in Communication Accommodation Theory. See the comparisons of the terms given, bellow:

Table 1.

Comparison Terms

\begin{tabular}{rll}
\hline No & Orbe & Giles \\
\hline 1 & Assimilation (non- Assertion) & - \\
2 & Accommodation & Convergence \\
3 & Aggressive & Divergence \\
4 & - & Over Accommodation \\
\hline
\end{tabular}

\section{Sasak}

This research is encompassing Sasak language use in central Lombok through accommodation in the form of convergence, switching or shifting amongst vernacular, see the details in Yassi (2019). As people know that language used in central Lombok mostly is Sasak language. The Sasak language owns many dialects that scattered around Lombok. The chance for society to use the dialect in social interactions widely opened. It can be applied at any time, place and even in particular situation, and it is in line with Khalik (2009) and Yassi $(2003,2016)$ that the situation is not accidentally happened but predictable. 
Sasak like other local languages separated around the world and lies within societies with its own culture. In fact, Sasak has also its own ways to communicate, since it is socioculturally different from another local language in other societies in the world as Gumperz \& Hymes (1972) in Khalik (2009). In terms of usage, certainty, the language is used in any different situation for different goals in different ways. Since, the goal of communication is to meet the agreement between the speakers, absolutely, it is applied any communication strategy, for instance, convergence as it is believed by many societies on average. Hymes (1972) believes that the goal of communication is gained through the constellation of the domain.

Consequently, the descriptions above are the pilot or basis of this research to develop, as stated in some parts of this article that, this research is to know the patterns of interdialectical accommodation among sellers-buyers in Lombok. Sasak does not only reflect the language but also the people. The language of Sasak is spoken by Sasak ethnic group who reside in Lombok. Most people speak Sasak. The language owns many varieties or dialects, as proposed by Mahsun (2006) from his research on dialectology diachronic he grouped the dialect into 4 parts based on the vowel correspondences, they are: Dialect of Bayan (DB) represented by the vowel a-a, dialect of Pujut (DP) represented by the a-e, Dialect of Selaparang (DS) represented by e-e, and Dialect of Aik Bukak (DA) represented by e-o. And the latest research by Mahyuni (2007) divided the dialect on social dialect into two categories, are base jamak and base alus.

The existence of those dialects shows their own prestige to the speakers of the dialects. For the dialects possess the uniqueness for the speakers. Besides, the presence of dialects is the gift from God also a prosperous culture in Lombok. More details, Husnan (2008) in Santana (2018) mentioned that the difference of dialect which is exist in Lombok is caused by the existence of the kingdom a long time ago.

Most of the Sasak native are Moslem of wektu lima five times signifies the five times daily prayer which required to do, Khalik (2009). This term is to differ the Sasak from wektu telu that signaled by three times doing prayer a day, long-long time ago. Even now we can still find it throughout the island of Lombok especially in North Lombok (Bayan).

\section{Geographic and Historical Factors}

Geography, given that the speakers of meriaq-meriku vs meno-mene are different background and also different people. They possibly meet each other and interact, since they also reside quite close to the other in terms of dialectal zone. This condition will be an impetus to converge when they talk to each other.

\section{RESEARCH METHOD}

This research is a sociolinguistics study and deals with the social phenomenon. Here the researchers employ the appropriate design for this research is qualitative interpretative research with the symbolic approach. The total subject used in this research is ten sellersbuyers from meriaq-meriku and meno-mene dialect. But, here the researchers simply present some parts of the data taken. Since the sellers-buyers in the market is very large, then the researchers use purposive sampling, while the object of this research is accommodation among sellers-buyers of people from meriaq-meriku while interact in the market. Much deeper this research encompasses the convergence among them. Basically, the data used in the qualitative research are taken through several activities and interactions in our daily life, like; birthday party, meeting, religious ceremonies, social processes and another group of the community, as recommended by Jonz \& Saville-Troike (2003). Since these activities provide 
very natural data deals with social interactions amongst people. The idea is also supported by Meyerhoff (2001) that the natural data can be gained through an interview in social activities consciously or unconsciously.

Hence, the primary data for this research is collected through factual dialog in daily communication in the market, particularly transaction discourse. and the data gains through three steps such as; observation, interviewing, capability adjustment, attitude judgement and documentation (recording, note-taking is as a compliment). The information is collected, clarified and sort it based on the need for the research. The researchersapply interpretative qualitative analysis. Here is a chart of data collection:

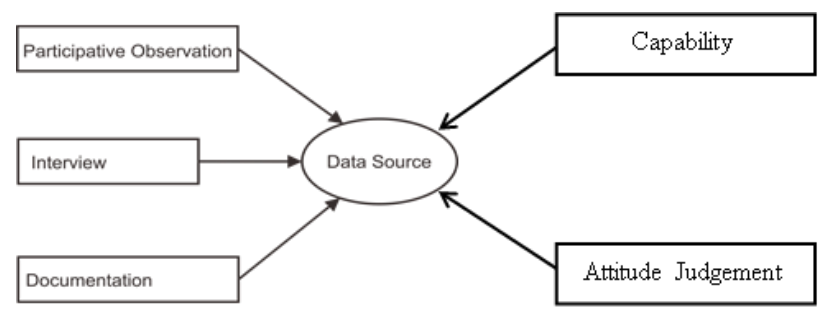

Chart 1

Data Collection

The object of this research are the sellers buyers at several markets in central Lombok and focus on the two dialects meriak-meriku vs meno-mene dialect. The sample use in this research are sellers of: meat, chicken, sickle, fruit, and vegetables. However, considering the data need for discussion, and then the researcher take the sample of conversation which is used as data analysis here is conversation between seller and buyer of sickle.

\section{DISCUSSION}

This part explains the research finding on the discourse among sellers-buyers in Sasak.

\section{Discourse among sellers-buyers}

In the following discussion, the researchers will depict the patterns of inter-dialectical Accommodation which is happened among sellers-buyers' discourse of Meriak-Meriku vs Meno-Mene dialect in Sasak.

Inter-dialectical accommodation or convergence between seller-buyer while interact in Bunkate market. The seller is a man named Jen. His age is thirty-two years old. He is from Berembeng, a part of central Lombok, that uses meno-mene dialect in daily speaking. While Marzuki is a man from Dasan Ketujur, a part of central Lombok, who speaks meriak-meriku dialect, and he is thirty-two years old of age.

Table 2

Conversation between Sellers and Buyers

\begin{tabular}{|c|c|c|}
\hline $\begin{array}{l}\text { Seller/ } \\
\text { buyer }\end{array}$ & Dialogues & Explanation \\
\hline $\mathbf{S}$ & $\begin{array}{l}\text { Tiye wah ...solah tiye bahann } \\
\text { d.prn adv adj d.prn } n \\
\text { lit: that exactly good that materials } \\
\text { T: Take that.....good material }\end{array}$ & $\begin{array}{l}\text { (B) alters his dialect into meno-mene } \\
\text { instead of his dialect of meriak-meriku. }\end{array}$ \\
\hline B & $\begin{array}{l}\text { Apek bahann menone? } \\
q w \quad n \quad c l \quad d . p r n \\
\text { lit: what material that this } \\
\text { T: What are the materials? }\end{array}$ & $\begin{array}{l}\text { The seller also alters his dialect to (B) } \\
\text { dialect. } \\
\text { Details of phenomenon is interpreted } \\
\text { below the table. }\end{array}$ \\
\hline $\mathbf{S}$ & $\begin{array}{l}\text { Pir mobil lamun sak iku jekn } \\
n \quad n \quad \text { if-cl cl d.prn unmarked } \\
\text { Lit: spring car if that d.prn - } \\
\text { T: Pedal in a car }\end{array}$ & - \\
\hline B & $\begin{array}{l}\text { Pire? } \\
\text { qw } \\
\text { lit: How }\end{array}$ & - \\
\hline
\end{tabular}




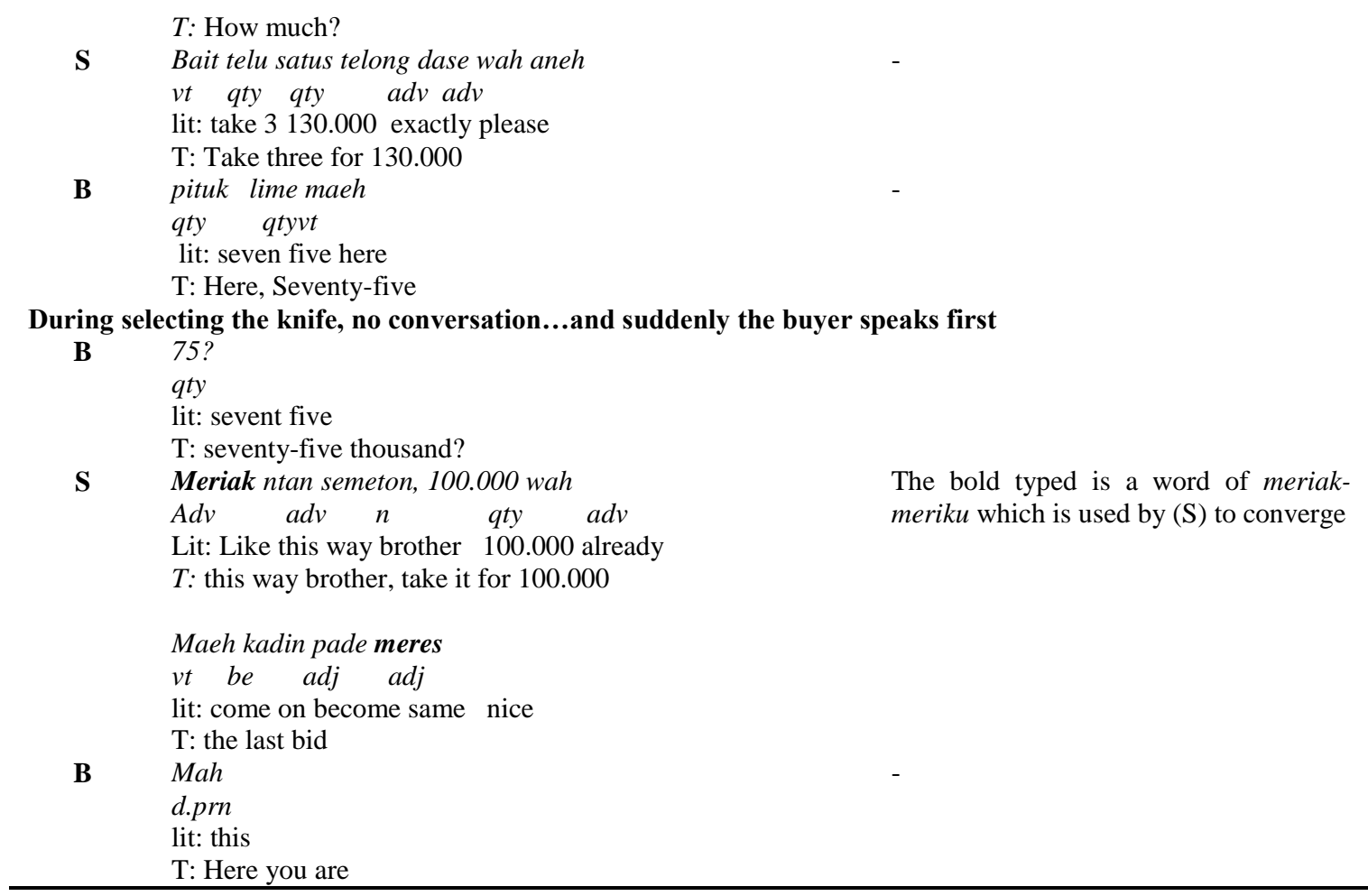

The table above displays a simple conversation between the seller and the buyer. The people who are involved in the conversation are from different background, (B) is a policeman who speaks Sasak with meriak-meriku dialect, and the (S) is a man who speaks Sasak with meno-mene dialect. In the conversation, the researcher find such a different thing, is that conversation of both men. Here, the researcher will break down the above conversation into some parts.

Here, in the conversation the (S) starts to address the (B) by saying "Tiye wah ...solahtiyebahann" this phrase is usually found in meno-mene dialect, and it is a common expression from the seller to make sure his candidate of the customer. There may appear in the reader's mind, how to identify that the phrase or sentence belongs to one's dialect. Giles \& Smith (1979) proposes some ideas how people are trying to converge between the speaker can be seen from; intonation, sound, and lexical. Further, Machmoed \& Yatim (2007) explain the convergence can be identified by looking at the dictions they adopted, pronunciation, and the language behavior. From the expression above beside the intonation of the speaker, we can recognize the dialect through next sentence of (B). For instance, apek bahann meno ne? This sentence, shows us that it is spoken by a man from meriak-meriku dialect, he uses dictions from meno-mene dialect while he expresses it in meriak-meriku dialect and the researcher recognizes this expression. The bold typed words above indicate that these words are meno-menedialect which is spoken by meriak-meriku man.

However, in the next sentence the readers can see, how (S) accommodates his language as similar as (B) dialect. In a glance, the words seem similar, but again we can identify the convergence through intonation, pronounce beside the lexical. Here are other sentences of the (S): Meriak tan semeton 100.000 wah isikmbaith kadinpade meres?. From thephrases, we can see how the (S) tries to converge or alters to the (B) dialect. Example: the word meriak tan, baith are actually spoken in meriak-meriku dialect. This expression is usually to make sure the (B) on something he/she heard. 
Through this phenomenon, the accommodation between them seems fine. they can produce dictions reciprocally one another. From small note of the interview that (B) accommodates himself in meno-mene dialect because of cultural value, while (S) does accommodation to include himself to (B) because he has another family member from meriak-meriku dialect. And he wants to show that he is also able to speak meriak-meriku dialect. In short, both interactants do convergence for phsychological aspect. Prior discussion was extended by Tani (2015:13) in her discussion she explained that speakers doing convergence to avoid the difference.

Another fact was also proved in different article by Muhid (2018, 2019), Muhid, Machmoed, \& Yassi (2020) it clarifies that one who alters to one's language or dialect prone to meet the point of agreement, since one's language used by other speakers of different background will bring a pride to the owner of language. Thus, how the accommodation bridges the speakers to meet the harmonization in interaction. In the article, the accommodation shows that how the communicators were helped to solve their problems or conflict among people not only seen through the alteration of language but also from the style and behaviors of the speakers and it is in line with Giles \& Smith (1979) as quoted in Elhami (2020). On the other work of Soliz \& Giles (2014:159) they depict that the accommodation happened to maintain the relationship among the speakers. Part of the conversation which is bold typed in the sample above indicates a strategy used by conversant that involved situational context, experience, and ability. This phenomenon was not only meets the accommodation theory by Giles (2016) but also co-cultural theory, as proposed by Orbe (2017). Further, it was strengthened by Nurwahid (2020).

Frequently, the convergence happens between speakers in communication by altering to a dialect of the interlocutor. Nevertheless, in the current research the researcher finds it is different. The speaker from meno-mene alters to meriak-meriku dialect, while the speaker from meriak-meriku alters to meno-mene dialect. Sees from the fact that both speakers of the dialect intensively meet and communicates among other people. As a result of this phenomenon, the distance of two dialects is not so far. In this way, the researchers concluded that both sellers-buyers have positive perception on the interdialectal accommodation. Meaning, more intense they meet create a conformity among them. The similar idea is also reinforced by Machmoed \& Yatim (2007), Muhid, Machmoed, \& Yassi (2020) in their article; they report that while two dialects are at dialect transition zone the diversity of lexical is low. As a result, the reciprocal convergence is happened. The phenomenon of reciprocal convergence is conceived at diagram below:

Chart 2

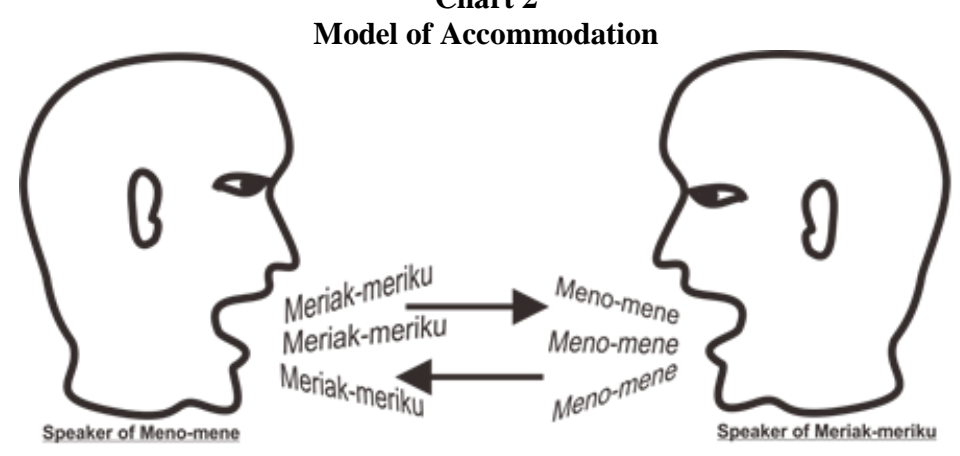

Source: Muhid, Machmoed, \&Yassi (2020:61) 


\section{Model of Accommodation}

The chart above clearly depicts how the accommodation happened between seller and buyer while conversing. Essentially, each of them show his ability to engage to another dialect, which he truly understands, this fact seems to reconfirm the idea reported by Machmoed \& Yatim (2007) in his article, about the cross dialect zone. Another idea from Wardhaugh \& Fuller (2015) they declared that the speakers do convergence to meet the expectation from the interlocutors, they can do this intentionally or unintentionally. Frankly, the theory of accommodation just try to explain one method of clarifying how people might be believed to identify with one another.

\section{CLOSING}

Through the analysis in the discussion above, it is found that there is a uniqueness of its dialect and the speakers from different dialect found difficulties to adapt as similar accent as the interlocutor. However, still it is considered positive since the message they intend to convey to the interlocutor is understandable, although his accent is not exactly the same as a native speaker of the dialect he follows, but in another case it is considered un-effective if the native speakers strictly fanatic on their dialect. In summary, this research reveals that the sellers-buyers perceive positive response on the inter-dialectal accommodation dealing with geographical background. Besides, that they are able to judge the interlocutor's origin through their accent. Nevertheless, this strategy of communication is effective to negotiate among the sellers and buyers.

\section{BIBLIOGRAPHY}

Andre, R. F. (2016). Akomodasi Komunikasi dalam Interaksi antar Budaya Pedagang Etnis Bugis dan Minang Kabau di Pasar Induk Talang Banjar Jambi. 3(1), 1-15. https://jom.unri.ac.id/index.php/-JOMFSIP/article/view/8681

Brennan, S. E., \& Clark, H. H. (1996). Conceptual Pacts and Lexical Choice in Conversation. Journal of Experimental Psychology: Learning Memory and Cognition, 22(6), 1482-1493. https://doi.org/10.1037/0278-7393.22.6.1482

Clark, H. H. (1996). Using Language. Stanford University, California. https://doi.org/10.1017/CBO9780511620539

Elhami, A. (2020). Communication Accommodation Theory: A Brief Review of the Literature. Journal of Advances in Education and Philosophy, 04(05), 192-200. https://doi.org/10.36348/jaep.2020-.v04i05.002

Giles, H. (2016). Communication Accommodation Theory. Cambridge University Press. https://doi.org/10.1017/CBO9781316226537

Giles, H., Coupland, J., \& Coupland, N. (1991a). Contexts of Accommodation (H. Giles, J. Coupland, \& N. Coupland (eds.)). Cambridge University Press. https://doi.org/10.1017/CBO9780511663673

Giles, H., Coupland, N., \& Coupland, J. (1991b). Accommodation theory: Communication, context, and consequence (pp. 1-68). University of Arizona Library. https://doi.org/10.1017/CBO9780511663673.001

Giles, H., \& Smith. (1979). Accommodation Theory: Optimal Levels of Convergence. in Howard Giles \& R. N. St. Clair (Eds), Language and Social Psychology (pp. 45-65). Oxford, UK: Blackwell.

Gumperz, J. J., \& Hymes, D. (1972). Direction in Sociolinguistics (J. J. Gumperz \& D. Hymes (eds.)). New York: Holt, Rinehart and Winston.

Hofstede, G. (1989). Organizing for cultural diversity. European Management Journal, 7(4), 397-7. https://doi.org/10.1016/0263-2373(89)90075-3

Hofstede, G. (2011). Dimensionalizing Cultures: The Hofstede Model in Context. Online Readings in Psychology and Culture, 2(1), 1-26. https://doi.org/10.9707/2307-0919.1014

Husnan, L. E. (2008). Penelitian Kekerabatan Bahasa-Bahasa Daerah: Tanah Asal dan Arah Migrasi Penutur Kosa Kata Alus Bahasa Sasak di Lombok. Departemen Pendidikan Nasional. Pusat 
Bahasa. Kantor Bahasa Nusa Tenggara Barat.

Hymes, D. (1972). On Communicative Competence. Penguin.

Jonz, J., \& Saville-Troike, M. (2003). The Ethnography of Communication: An Introduction. In TESOL Quarterly (Vol. 18, Issue 4). https://doi.org/10.2307/3586585

Khalik, L. A. (2009). The Pattern of Sasak Choice: A Sociolinguistics Study. PPs UNHAS Makassar.

Labov, W. (2010). Principle of Linguistic Change: Cognitive and Cultural Factors (1st ed.). WileyBlackwell. https://doi.org/10.1002/9781444327496

Lambert, W. E., Hodgson, R. C., Gardner, R. C., \& Fillenbaum, S. (1960). Evaluational reactions to spoken languages. The Journal of Abnormal and Social Psychology, 60(1), 44-51. https://doi.org/10.1037/h0044430

Machmoed, H. A., \& Yatim, N. (2007). Digital Language Death. Masyarakat Linguistik Inonesia, 25(1). https://doi.org/10.1371/journal.pone.0077056

Mahsun. (2006). Kajian Dialektologi Diakronis Bahasa Sasak di Pulau Lombok. Gama Media.

Mahyuni. (2007). Social Change and the Sasak Traditional Speech Conventions. Linguistik Indonesia, $25(2), 1-10$.

Meyerhoff, M. (2001). Introducing Sociolinguistics Miriam Meyerhoff. Language, 77, 1-352. https://doi.org/10.4324/9780429507922-1

Muhid, A. (2018). Akomodasi Sebagai Strategi Menyelesaikan Konflik dalam Sidang Perselingkuhan. In Humanitatis: Jounal of Language \& Literature (Vol. 5, Issue 1, pp. 78-84). Humanitatis.

Muhid, A. (2019). Inter-dialectical Accommodation in Sasak; Revisiting the Universality of Giles' Convergence Theory. Universitas Hasanuddin Makassar.

Muhid, A., Machmoed, H. A., \& Hakim Yassi, A. (2020). Convergence as a Communication Strategy (1st ed.). Yayasan Barcode.

Muhid, A., Machmoed, H. A., \& Yassi, A. H. (2020). Factors Affecting the Effectiveness of InterDialectical Accommodation among the Sellers-Buyers Discourse. ELS Journal on Interdisciplinary Studies in Humanities, 3(2), 170-178. https://doi.org/10.34050/elsjish.v3i2.10264

Nurwahid, A. F. (2020). Interaksi Kelompok Punk dengan Netizen (p. 15). Jurusan Ilmu Komunikasi. https://ejournal3.undip.ac.id/index.php/interaksi-online/article/view/16560/15937

Orbe, M. P. (2017). Critical Intercultural Communication Theories, Issues, and Concepts. In Co-Cultural Theory (pp. 1-14). Wiley. https://doi.org/10.1002/9781118783665.ieicc0201

Preston, D. R. (1989). Perceptual Dialectology. De Gruyter Mouton. https://doi.org/10.151519783110871913

Robert, L. M. (1999). Immigrant language maintenance and shift in Gujarati, Dutch and Samoan Communities of Wellington [Victoria University of Wellington]. http://hdl.handle.net/10063/1311

Santana, L. (2018). Eliticism Acknowledgement Among Achieved High Social Status Group in Sasak Community on Sociopragmatic. PPs UNHAS Makassar.

Shameem, N. (1995). Bilingualism. Oxford: Oxford University.

Soliz, J., \& Giles, H. (2014). Relational and Identity Processes in Communication: A Contextual and Meta-Analytical Review of Communication Accommodation Theory. Annals of the International Communication Association, 38(1), 107-144. https://doi.org/10.1080/23808985.2014.11679160

Tani, M. (2015). Accommodation Theory in Interlanguage Talk: Convergence across Different Levels of English. Tokyo University of Foreign Studies.

Trudgill, P. (2003). A glossary of sociolinguistics. Oxford: Oxford University Press.

Wardhaugh, R., \& Fuller, J. M. (2015). An Introduction to Sociolinguistics (7th ed.). Wiley-Blackwell.

Yassi, A. H. (2003). Code-Swithcing as a Communication Strategy in Indonesia-English Billingual Discourse: A Congruence-Functional Approach to Indonesian to Indonesian-English CodeSwitching. PPs UNHAS Makassar.

Yassi, A. H. (2016). Code Switching as Communication Startegy (1st ed.). Trust Media Publishing.

Yassi, A. H. (2019). Ancangan Model Kerangka Teori Kesantunan yang Efektif Mengkaji Budaya Bahasa-Bahasa Heritage di Asia: Review terhadap Keuniversalitasan Kerangka Teori Kesantunan Brown \& Levinson. Linguistik Indonesia, 35(2), 159-186. https://doi.org/10.26499$\underline{\text { li.v35i2.68 }}$ 